\title{
New records of mealybug species in Iran with discussions on morphological variations (Hemiptera, Coccoidea: Pseudococcidae)
}

\section{Masumeh Moghaddam}

\begin{abstract}
Moghaddam, M. 2015: New records of mealybug species in Iran with discussions on morphological variations (Hemiptera, Coccoidea: Pseudococcidae). Entomol. Fennica 26: 122-131.
\end{abstract}

The mealybug Vryburgia succulentarum Williams is recorded for the first time from the Palaearctic area (in a greenhouse). In addition, four other species, Artemisia bispinus (Borchsenius), Coccura circumscripta (Kiritchenko), Mirococcus inermis (Hall) and Phenacoccus daganiae (Bodenheimer) are recorded for the first time from Iran. Artemisia bispinus, C. circumscripta and P. daganiae have been reported only from the Palaearctic Region. The third-instar female of $M$. inermis is described based on specimens collected in Iran. Some characters of $A$. bispinus, $C$. circumscripta and $M$. inermis differ from those in the specimens found elsewhere and are discussed. Illustrations, localities and host plants of the above species are provided.

M. Moghaddam, Insect Taxonomy Research Department, Iranian Research Institute of Plant Protection, P.O. Box 1454-19395, Tehran, Iran; E-mails: moghadam@iripp.ir,moghaddamm2002@yahoo.com

Received 2 March 2015, accepted 15 April 2015

\section{Introduction}

The family Pseudococcidae, commonly known as the mealybugs, is the second largest family within scale insects (Hemiptera: Sternorrhyncha: Coccoidea), with 2,000 described species in 263 genera all over the world (Ben-Dov et al. 2015).

Studies of the Iranian scale insects extend from long ago until now by Iranian and foreign coccidologists. Moghaddam (2013a, b) gave recently details about these literatures. According to the latest published paper (Moghaddam 2013b), 56 recorded mealybug species are in Iran. The present paper deals with new mealybug records in Iran, including illustrations, hosts and geographical distributions.

\section{Materials and methods}

The mealybug specimens were collected in different areas of Iran. The specimens were taken from wild plants. Collecting data, including locality (name of the province, city, GIS coordinates, etc.), date of collection, collector name, scientific name of the host plant and finally the number of the studied specimens are reported. Each sample was put into a $75 \%$ alcohol tube in the field and taken to the laboratory for examination. The specimens were slide mounted according to the procedure of Williams and Granara de Willink (1992) and the terminology follows that of Williams (2004).

Each illustration shows the morphology of 
dorsum on the left and the morphology of venter on the right with enlargements of important characters around the edges. These enlargements are not drawn to scale.

Abbreviations for the depositories are as follows:

- HMIM (Hayk Mirzayans Insect Museum), IRIPP (Iranian Research Institute of Plant Protection, Tehran, Iran)

- ZISP (Zoological Institute Russian Academy of Science, Russia)

- NHMUK (Natural History Museum, London, $\mathrm{UK})$

- ANIC (Australian National Insect Collection, Australia).

\section{New records of mealybug species for Iran}

Among the studied mealybug specimens from different areas of Iran, five species proved to be new records for the Iranian fauna. Among them, Mirococcus inermis was identified from specimens preserved in Hayk Mirzayans Insect Museum (HMIM) and Vryburgia succulentarum is an alien invasive pest.

According to this study, the number of Pseudococcidae of Iran is increased to 61 species.

\subsection{Artemisia bispinus (Borchsenius) (Fig. 1)}

Centrococcus bispinus Borchsenius, 1949: 309; Centrococcus unispinus Borchsenius, 1949: 310. Syntype adult $q$, Turkmenistan, Firuz, on Artemisia sp. (Asteraceae), (ZISP).

Material examined. Khorasan -e Shomali: Esfarayen, Salook National Park, $6 \uparrow q$, on Artemisia sp. (Asteraceae), 21.VI.2012, 3709'20.9” N, $57^{\circ} 16 ’ 24.5^{\prime \prime}$ E, 1,190 m a.s.1., M. Moghaddam leg.

Diagnostic characters (Borchsenius (1949) with additions). In nature, adult female on the distal end of herbaceous stem of host plants. Mounted adult female oval to broadly oval. Antennae 7-segmented. Claw with a denticle. Ostioles and circulus absent. Cellular plates of irregular form on dorsum of head and thorax. Cerarii numbering 15 pairs, each with $2-5$ enlarged coni- cal setae and 2 or 3 trilocular pores, present on flat and weakly sclerotised areas. Dorsal surface with setae similar to cerarian setae, most grouped into dorsal cerarii. Few multilocular disc pores on dorsal abdominal segments VII and VIII; and as transverse rows on posterior edges of ventral segments IV-VII and posterior of vulva. Quinqelocular pores present on midline and submedian of venter. Tetralocular pores around spiracles. Trilocular pores scattered on whole dorsum. Numerous dorsal tubular ducts and trilocular pores distributed along ventral margins of body.

Comments. The Iranian specimens of $\mathrm{A}$. bispinus differ in some respects from the description by Borchsenius (1949), Ter-Grigoiran (1973) and Danzig et al. (2012) as follows (character states of specimens described by the latter authors in brackets): (i) most of cerarii with 2-5 setae [maximum 2 setae], (ii) dorsal cerarii in longitudinal rows [not in longitudinal rows].

The genera Coccidohystrix Lindinger and Artemisia Balachowsky were revised first by Kozár and Pellizzari Scaltriti (1989), Gavrilov-Zimin and Matile-Ferrero (2014) and also Danzig and Gavrilov (2014a). The latter name is considered as a subjective junior synonym of Coccidohystrix.

There are some critical points. The genus Coccidohystrix differs by having abnormal cerarii, which are replaced by groups of large conical setae associated with discoidal pores, not trilocular; and all cerarii are situated on the elevated sclerotised plates. These two important characters are not in the genus Artemicoccus. Here it is suggested that molecular methods can solve this controversial subject. Artemicoccus differs in two main characters from Coccidohystrix as follows (character states of the latter species in brackets): (i) cerarii with trilocular pores [cerarii with discoidal pores] and (ii) all cerarii situated on dorsum [all cerarii located on elevated sclerotised plates]. In view of this situation, this paper follows the separation of these genera.

\subsection{Coccura circumscripta (Kiritchenko)} (Fig. 2)

Mediococcus circumscriptus Kiritchenko, 1936: 144. Syntype adult 9 , Turkmenistan, Chod- 


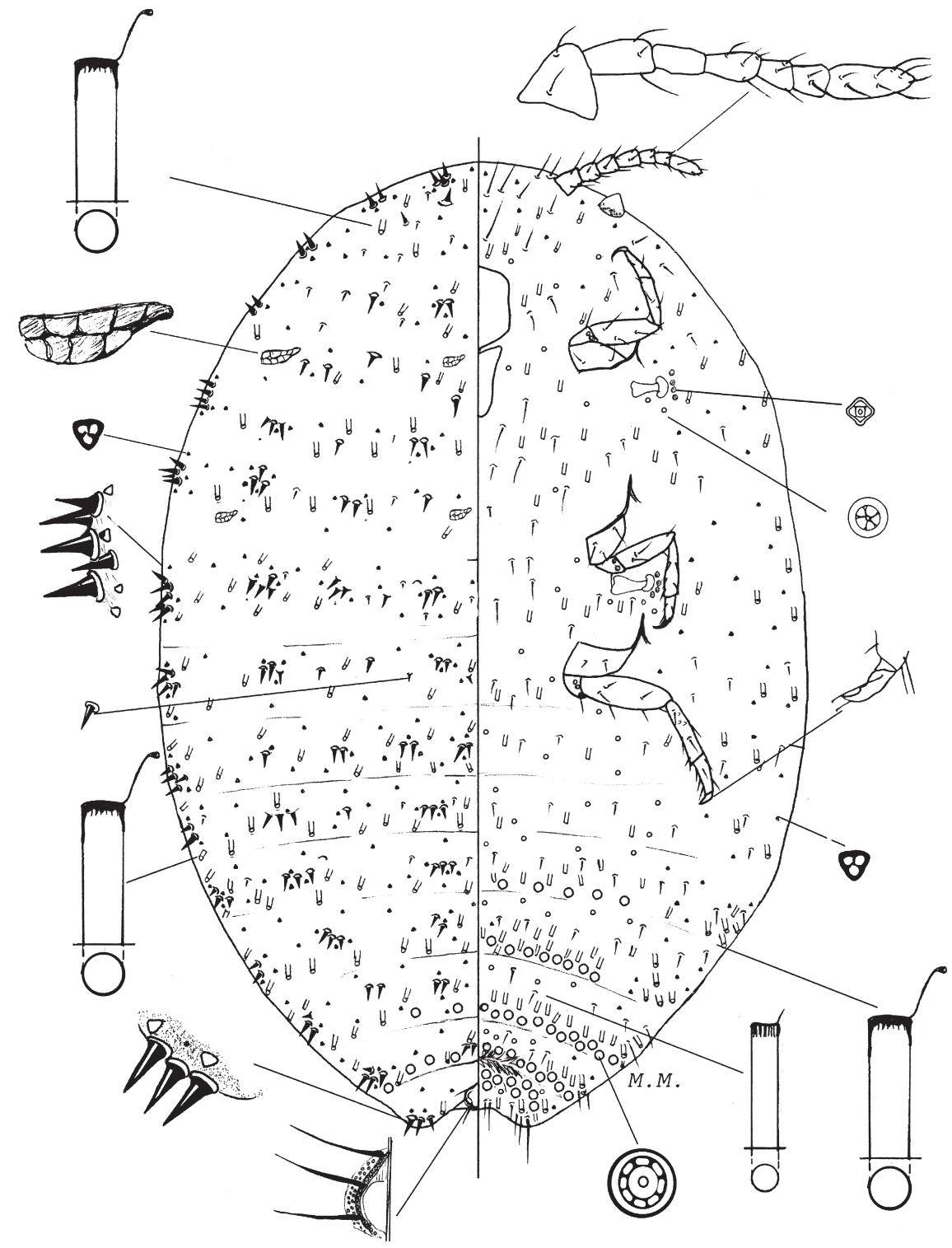

Fig. 1. Adult female Artemicoccus bispinus (Borchsenius). zhent District, Mongol-tau, on Athraphaxis pyrifolia (Polygonaceae), (ZISP).

Coccura transcaspica Borchsenius, 1949: 304.

Syntype adult ${ }_{+}$, Turkmenistan: on Atraphaxis sp., (ZISP). Synonymy by Danzig, 2012: 647.

Material examined. Kerman: Kerman, Koohpayeh, 11 + , on Noaea mucronat (Amaranthaceae), 16.V.2011, 30³1'01.9' N, 57 $10^{\circ}$ '54.0" E, 2,655 m a.s.1., M. Moghaddam leg.

Diagnostic characters (Borchsenius (1949) with additions). Mounted female broadly oval, tapering to head and prothorax. Antennae 8-segmented. Claw with a small denticle. Anal ring present slightly distant from posterior margin of body, and with 2 incomplete rows of pores. Circulus numbering 3. Apparently without ostioles. Cerarii in 2 pairs; anal lobe cerarii with 2 large lanceolate setae, and $\mathrm{C}_{17}$ with a single smaller lanceolate seta. Dorsal setae small and lanceolate. Multilocular disc pores present on ventral median areas of posterior abdominal segments. Quinquelocular pores present on ventral 


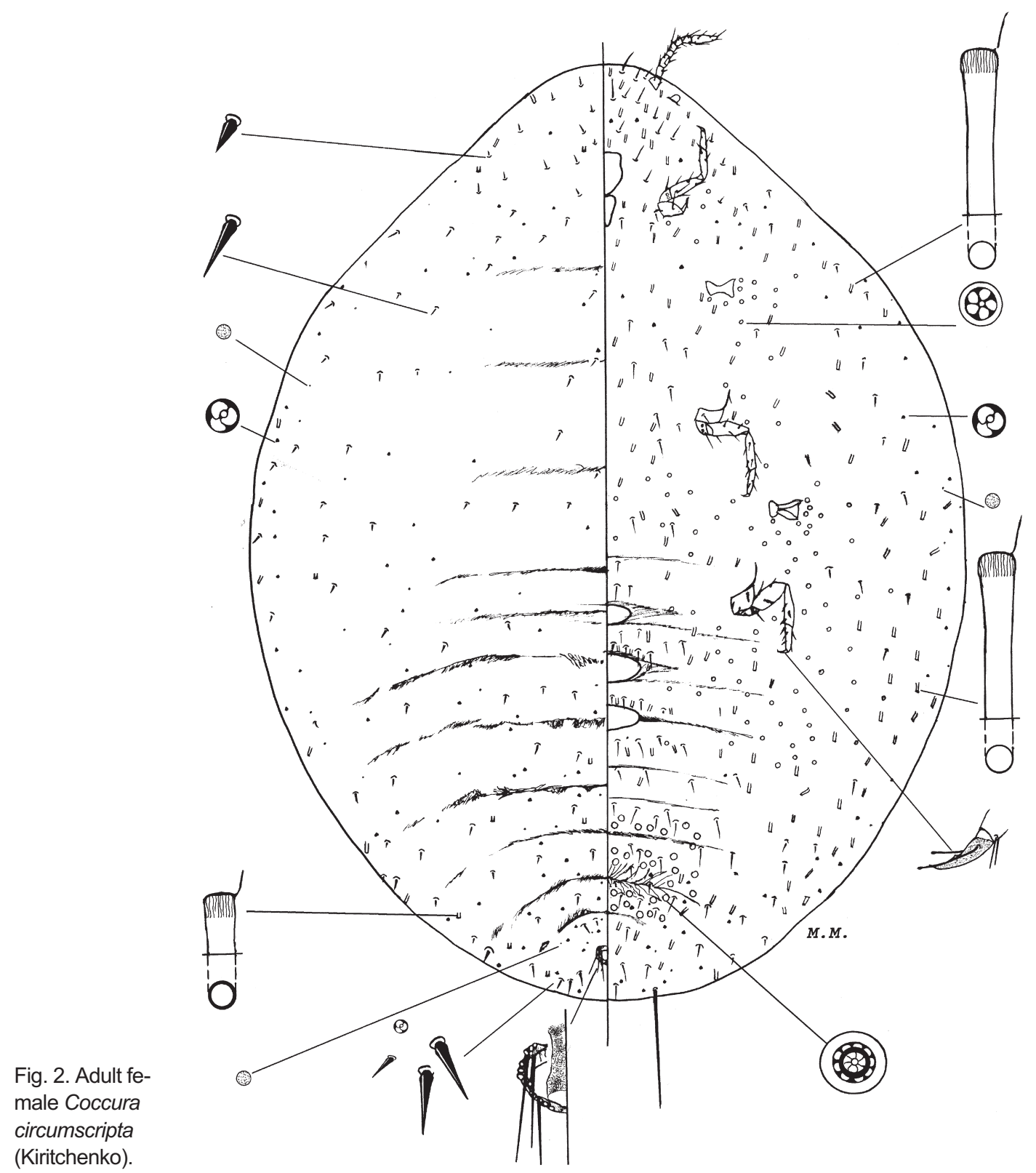

thorax and abdominal segments and also concentrated back of spiracles. Trilocular pores scattered on dorsum and margins of venter. Simple tubular oral ducts on dorsal margin and bottle-shaped tubular ducts scattered on venter.

Comments. The genus Coccura Šulc is a Palaearctic genus, consisting of four species recorded in Russia and republics of the former USSR (Ben-Dov et al. 2015). The Iranian specimens of $C$. circumscripta differ from specimens described by Danzig (2012) and Ter-Grigorian (1973) from Russia as follows (character states of the specimens described by the latter authors in brackets): (i) body about $3.60 \mathrm{~mm}$ long and about $3.40 \mathrm{~mm}$ wide [2.2 $\mathrm{mm}$ long], (ii) antennae 8 -segmented [9-segmented], (iii) dorsal setae and cerarian setae lanceolate [conical], (v) quinquelocular pores medially on ventral thorax and abdominal segments I-IV [only present on thoracic segments]. 


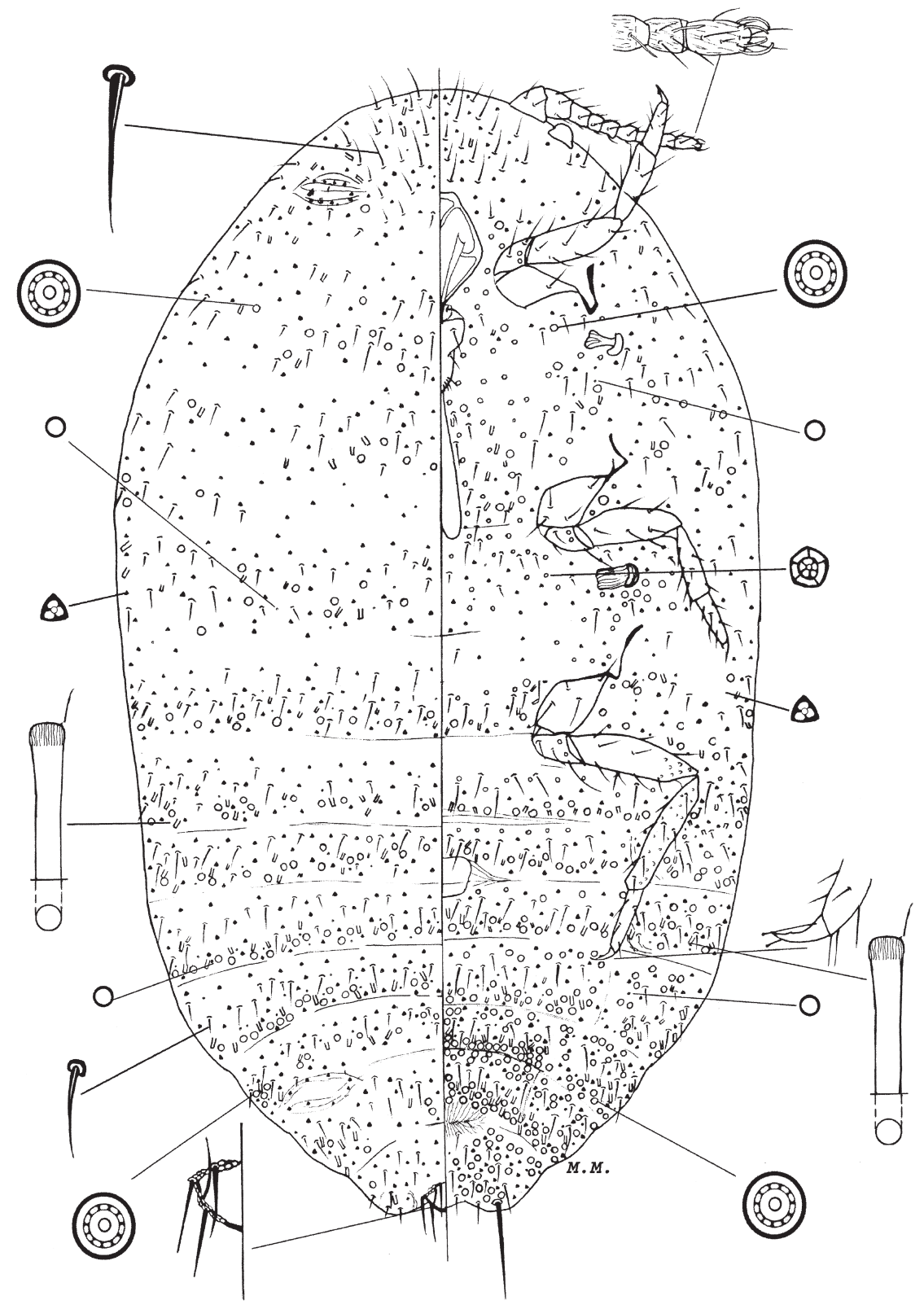

Fig. 3. Adult female Mirococcus inermis (Hall).

The host plant, N. mucronat (Amaranthaceae), is new for $C$. circumscripta.

\subsection{Mirococcus inermis (Hall) (Fig. 3)}

Phenacoccus inermis Hall, 1925: 7. Holotype adult + . Egypt: Helwan, on roots of Zygophyllum simplex (NHMUK).

Material examined. Sistan \& Balouchestan: un- known locality, 2 adult $+\circ, 2$ third-instar $\odot \rightarrow$, on Noaea sp. (Chenopodiaceae), 10.V.1950, collector not known.

Diagnostic characters (Borchsenius 1949). Antenna 9-segmented. Claw stout with a small denticle. Translucent pores on hind femur and tibia. Circulus divided by an intersegmental line. Anterior and posterior ostioles present. Cerarii absent. Multilocular disc pores numerous across all dorsal and ventral segments. Quinquelocular 


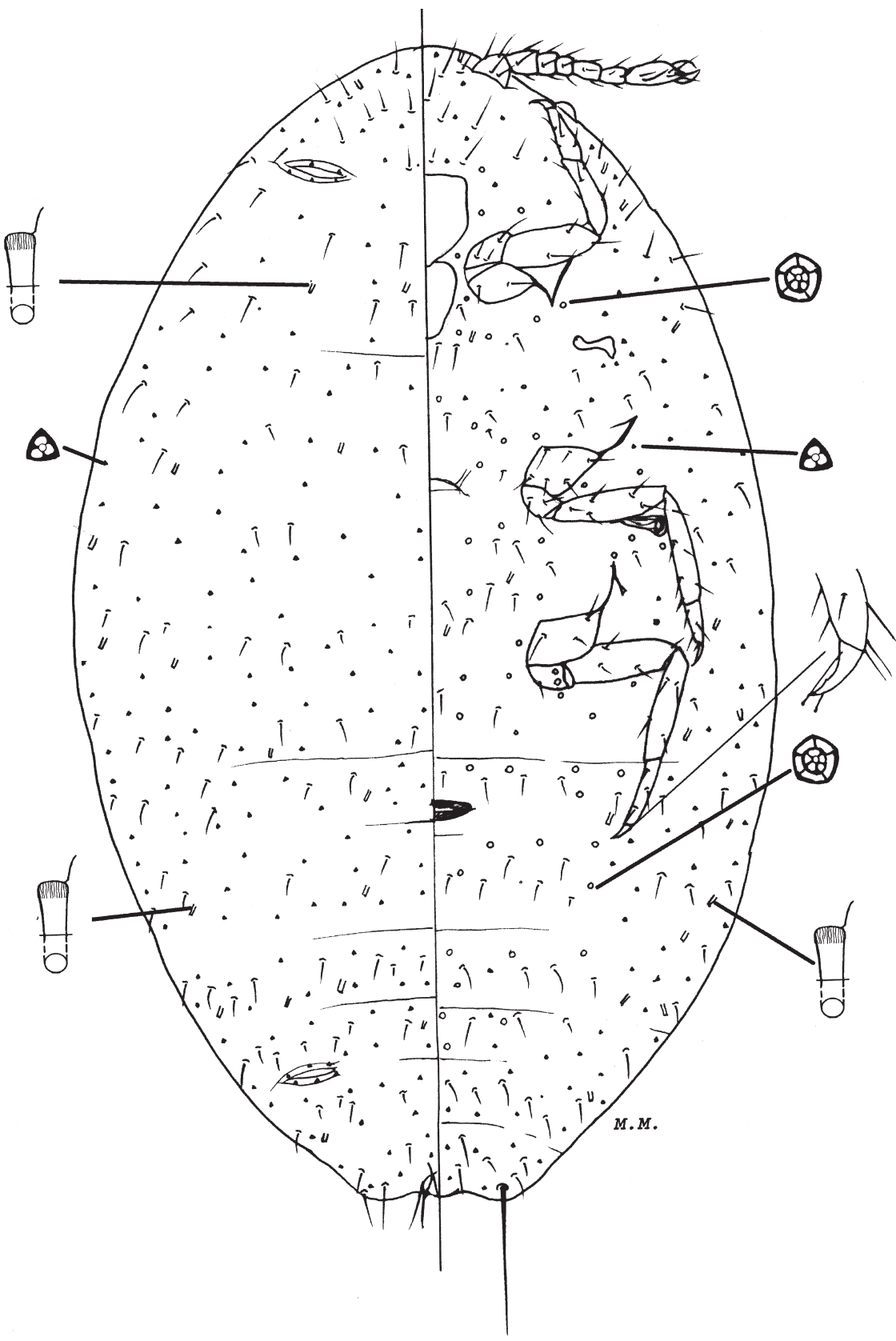

Fig. 4. Third-instar female Mirococcus inermis (Hall).

pores fairly numerous in medial areas of thorax and abdominal segments I-IV. Oral collar tubular ducts on both sides.

Comments. According to the recent revision of Danzig and Gavrilov-Zimin (2014b) the genus comprises 12 species mostly Palaearctic in distribution with the exception of $M$. inermis recorded also in the Afrotropical (Sudan).
Mirococcus inermis is a polyphagous species and occurs on about 18 host plant families; Noaea sp. (Chenopodiaceae) is a new host plant of this species.

3.3.1. Description of the third-instar female Mirococcus inermis (Hall) (Fig. 4)

Diagnostic characters. Body oval, about $1.8 \mathrm{~mm}$ 


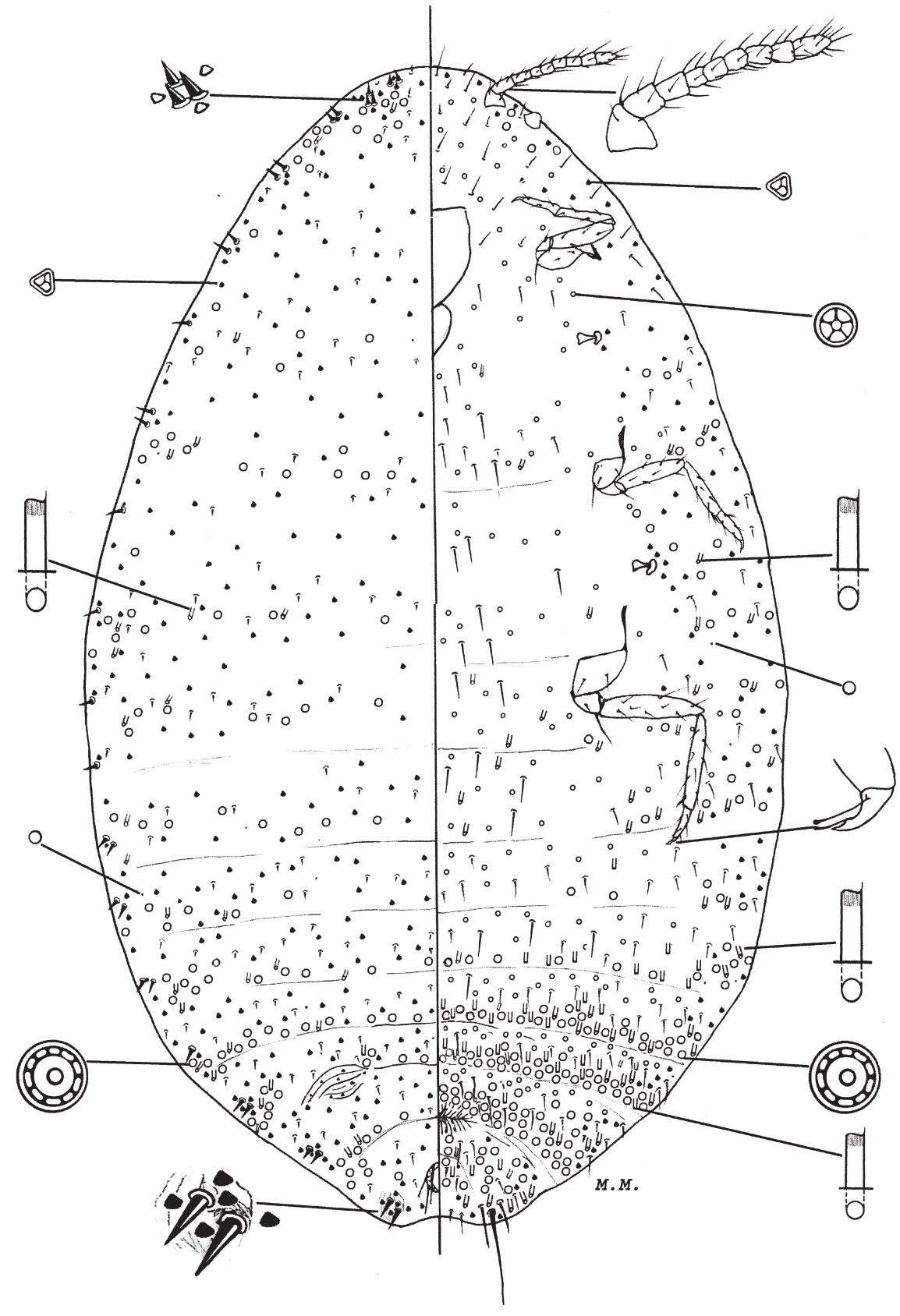

Fig. 5. Adult female Phenacoccus daganiae (Bodenheimer). long and $1.12 \mathrm{~mm}$ wide. Antennae 7-segmented, about $320 \mu \mathrm{m}$ long. Legs well developed; trochanter + femur about $190 \mu \mathrm{m}$ long, tibia + tarsus about $230 \mu \mathrm{m}$ long. Ratio of lengths of hind tibia + tarsus to hind trochanter + femur about $1: 1.31$; ratio of lengths of hind tibia to hind tarsus about 1:1.4; claw slender, with a denticle, about $30 \mu \mathrm{m}$ long. Anal lobe well developed, each with an apical seta about $130 \mu \mathrm{m}$ long. Anal ring about $50 \mu \mathrm{m}$ wide, bearing 6 setae, each about $35 \mu \mathrm{m}$ long. Circulus oval, about $75 \mu \mathrm{m}$ wide, sclerotised, divided by an intersegmental line. Both anterior and posterior ostioles well developed. Cerarii absent.

Dorsal surface with slender setae, mostly each about $25 \mu \mathrm{m}$ long. Trilocular pores evenly dis- 


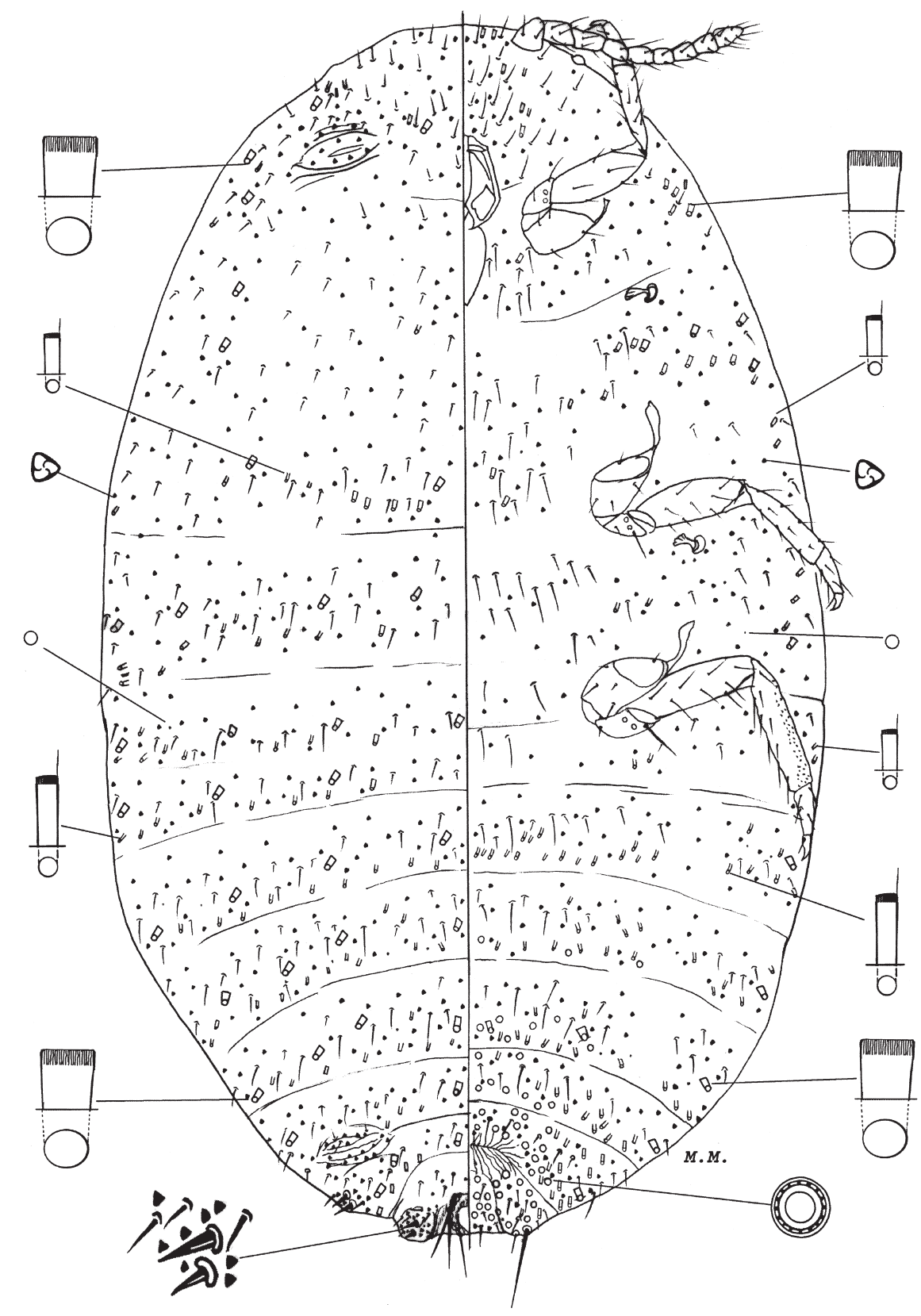

Fig. 6. Adult female Vryburgia succulentarum Williams.

tributed. Oral collar ducts small, each about $5 \mu \mathrm{m}$ long, few, on head, thorax and abdominal segments, except abdominal segment VIII.

Ventral setae similar as those on dorsum, but slightly larger. Quinquelocular pores each about $8 \mu \mathrm{m}$, medially on head, thorax and abdominal segments I-VI. Trilocular pores each about $4 \mu \mathrm{m}$, evenly dispersed. Oral collar ducts similar as those on dorsum, scattered on head, thorax and abdominal segments, except abdominal segments VIII and IX.

Comments. All material of the adult females and the third-instar females have been collected together.

\subsection{Phenacoccus daganiae (Bodenheimer)} (Fig. 5)

Pseudococcus daganiae Bodenheimer, 1926: 
191, Lectotype adult 9 , Israel: Deganya, on Cynodon dactylon (Poaceae), Department of Entomology, The Volcani Center, Israel.

Peliococcus armeniacus Borchsenius, 1949: 253.

Lectotype adult ${ }_{+}$, Armenia: Erevan, on $C$. dactylon, (ZISP). Synonymy by Danzig, 2001: 136.

Material examined. Tehran, Damavand, on Cynodon dactylon (Poaceae), 7 adult 9 오, 20.VIII.2014, 3544'17.1” N, 52॰09'51.9” E, F. Parsi leg.

Diagnostic characters (Ter-Grigorian 1973). Antennae 9-segmented. Claw without a denticle. Cerarii numbering 18 pairs, most with 2 conical setae and also 2-4 trilocular pores, some with 1 conical seta, and $\mathrm{C}_{2}$ with 3 setae. Circulus absent. Anterior and posterior ostioles present. Multilocular pores on dorsum distributed in transverse rows on thorax and abdominal segments, and also grouped by $2-3$ around margins; on venter, multilocular pores across abdominal segments and also on margins of thorax and head. Quinquelocular pores on venter only. Oral collar tubular ducts of two sizes, but difference in size inconspicuous.

Comments. Recently, three species, Peliococcus daganiae, P. orientalis Bazarov and Spinococcus giuliae Pellizzari are transferred to Phenacoccus daganiae (Bodenheimer). These species lack the diagnostic character states of the genus Peliococcus as rediagnosed. They lack: (i) clusters of multilocular disc pores and/or oral collar tubular ducts, (ii) enlarged setae on dorsum, similar to cerarian setae, (iii) trilocular pores near the basal socket of all dorsal setae, which are not on elevated areas, and (iv) cerarii on elevated areas (Kaydan 2015). Furthermore, the difference between small and large tubular ducts is not conspicuous in Peliococcus.

\subsection{Vryburgia succulentarum Williams} (Fig. 6)

Vryburgia succulentarum Williams, 1985: 388. Holotype adult $\uparrow$, Australia: Tasmania, Ulverstone, on Sedum sp. (Crassulaceae), (ANIC).

Material examined. Tehran, Evin, 14 adult $ㅇ$, on Crassula sp. (Crassulaceae) (greenhouse),
14.IV.2014, 3547’31.5” N, 51²4’36.8” E, M. Moghaddam leg.

Diagnostic characters (Williams 1985). Adult female broadly oval. Antennae 9-segmented. Translucent pores numerous, on hind tibia only. Claw stout with a small denticle. Circulus absent. Anterior and posterior ostioles present. Cerarii numbering 2 pairs, on anal lobes and abdominal segment VII. Anal lobe cerarii with 2 enlarged conical setae, rarely with 1 smaller conical seta, and also with some auxiliary setae and a group of trilocular pores. Dorsal surface with short slender setae. Dorsal multilocular disc pores absent in Iranian specimens, but sometimes present a few in median areas of last abdominal segments; ventral multilocular disc pores medially on abdominal segments IV-VII and posterior to vulva. Trilocular pores and discoidal pores evenly dispersed on dorsum and venter. Dorsal oral collar ducts of three types, all forming rows across middle of dorsal segments. Large types on margins of ventral thorax and abdomen.

Comments. This species can be separated easily from $V$. amaryllidis (Bouché) in having wide oral ducts instead of rows of oral rim ducts on dorsum. The genus Vryburgia De Lotto consists of ten species at present, mostly from Africa, often feeding on succulents (Williams 2004). Vryburgia amaryllidis (Bouché) was previously reported in Iran (Moghaddam 2013a). Vryburgia succulentarum has been described based on specimens collected in Australia from succulents (Aizoaceae, Cactaceae, Crassulaceae), but according to D. J. Williams (pers. comm.) this species could have been introduced in Iran via plant trade from African or other southern countries. At present, the pest status of this species in Iran has not yet been assessed.

\section{References}

Ben-Dov, Y., Miller, D. R. \& Gibson, G. A. P. 2015: ScaleNet. [www document]. URL http://www.sel.barc.us$\mathrm{da} /$ scalenet/scalenet.htm. (Site visited on 20 February, 2015.)

Bodenheimer, F. S. 1926: Second note on the Coccidae of Palestine. - Bulletin of Entomological Research 17: 189-192.

Borchsenius, N. S. 1949: Insects Homoptera. suborders mealybugs and scales (Coccoidea). Family mealybugs 
(Pseudococcidae). Vol. VII Fauna SSSR. - Zoologicheskii Institut Akademii Nauk SSSR, N.S. 38: 1-382.

Danzig, E. M. 2001: Mealybugs of the genera Peliococcus and Peliococcopsis from Russia and neighbouring countries (Homoptera: Coccinea: Pseudococcidae). —Zoosystematica Rossica 9(1): 123-154.

Danzig, E. M. 2012: Revision of the Mealybug Genus Coccura Sulc, 1908 (Homoptera, Coccinea: Pseudococcidae). - Entomological Review Vol. 92, No. 6: 642-649.

Danzig E. M., Gavrilov-Zimin I. A. 2014a: Palaearctic mealybugs (Homoptera: Coccinea: Pseudococcidae). Part 1. Subfamily Phenacoccinae. - Zoological Institute of the Russian Academy of Science, Saint-Petersburg. 678 pp. (Fauna of Russia and neighbouring countries. New series, No. 148. Insecta: Hemiptera: Arthroidignatha).

Danzig, E. M. \& Gavrilov-Zimin, I. A. 2014b: Mealybugs of Mirococcus Borchsenius, 1947 Genus-Group (Homoptera, Coccinea: Pseudococcidae). — Entomological Review Vol. 94(2): 231-244.

Danzig, E. M., Kaydan, M. B. \& Gavrilov-Zimin, I. A. 2012: A review of Palaearctic species of Artemicoccus and Coccidohistrix (Homoptera: Coccinea: Pseudococcidae). - Zoosystematica Rossica 21(2): $237-$ 243.

Gavrilov-Zimin, I. A. \& Matile-Ferrero, D. 2014: The genus Coccidohystrix Lindinger, 1943 in the Palaeartic Region with description of two new species from Maghreb (Homoptera: Coccinea: Pseudococcidae). —Zoosystematica Rossica, 23(1): 96-105.

Hall, W. J. 1925: Notes on Egyptian Coccidae with descriptions of new species. - Bulletin, Ministry of Agriculture, Egypt, Technical and Scientific Service 64: $1-31$.
Kaydan, M. B. 2015: A systematic study of Peliococcus Borchsenius (Hemiptera: Coccoidea: Pseudococcidae), with descriptions of a new Palaearctic genus and four new species from Turkey. — Zootaxa 3920(2): 201-248.

Kiritchenko, A. N. 1936: Some new Pseudococcinae of the fauna of USSR (Hemiptera, Coccoidea). - Revue d'Entomologie de l'USSR 26: 130-159.

Kozár, F. \& Pellizzari Scaltriti, G. 1989: A new mealybug from Italy: Coccidohystrix zangherii sp. n. - Estratto da Redia, Vol. LXXII, n. 2: 507-511.

Moghaddam, M. 2013a: A review of the mealybugs (Hemiptera: Coccoidea: Pseudococcidae, Putoidae and Rhizoecidae) of Iran, with descriptions of four new species and three new records for the Iranian fauna. Zootaxa 3632(1): 001-107.

Moghaddam, M. 2013b: An annotated checklist of the scale insects of Iran (Hemiptera, Sternorrhyncha, Coccoidea) with new records and distribution data. - ZooKeys 334: 1-92.

Ter-Grigorian, M. A. 1973: Fauna of the Armenian SSR. Fauna of the Armenian SSR: Scale insects (Coccoidea, Pseudococcidae). - Akademii Nauk Armiansky SSR, Erevan, Armenia. 246 pp.

Williams, D. J. 1985: Australian Mealybugs. — British Museum (Natural History), London. 431 pp.

Williams, D. J. 2004: Mealybugs of Southern Asia. — The Natural History Museum, Kuala Lumpur: Southdene Sendirian Berhad, 896 pp.

Williams, D. J. \& Granara de Willink, M. C. 1992: Mealybugs of Central and South America. - Commonwealth Agricultural Bureau International, London, England. 635 pp. 